PLANTS PEOPLE

POSSIBILITIES

\title{
Chinese Rhododendrons: Determinations and Descriptions of New Species
}

\section{Author(s): W. Botting Hemsley and E. H. Wilson}

Source: Bulletin of Miscellaneous Information (Royal Botanic Gardens, Kew), Vol. 1910 , No. 4 (1910), pp. 101-120

Published by: Springer on behalf of Royal Botanic Gardens, Kew

Stable URL: http://www.jstor.org/stable/4114334

Accessed: 27-06-2016 03:21 UTC

Your use of the JSTOR archive indicates your acceptance of the Terms \& Conditions of Use, available at

http://about.jstor.org/terms

JSTOR is a not-for-profit service that helps scholars, researchers, and students discover, use, and build upon a wide range of content in a trusted digital archive. We use information technology and tools to increase productivity and facilitate new forms of scholarship. For more information about JSTOR, please contact support@jstor.org.

Royal Botanic Gardens, Kew, Springer are collaborating with JSTOR to digitize, preserve and extend access to Bulletin of Miscellaneous Information (Royal Botanic Gardens, Kew) 
ROYAL BOTANIC GARDENS, KEW.

\author{
B U L L E T I N
}

\title{
or MISCELLANEOUS INFORMATION.
}

No. 4.]

$[1910$.

\section{XVI.-CHINESE RHODODENDRONS : Determinations and Descriptions of New Species.}

W. Botting Hemsley and E. H. Wilson.

I.- Introduction.

Towards the end of 1906, and just previous to his departure on a third mission to China, Mr. E. H. Wilson devoted a considerable amount of time to the determination of the magnificent dried collections of Rhododendrons made on his two previous journeys, while Mr. W. B. Hemsley afforded him as much assistance as it was possible to give in unofficial hours. The intention was to publish jointly descriptions of the new species, on the plan followed in "Some New Chinese Plants," which appeared in the Kew Bulletin for 1906, pp. 147-163. Mr. Wilson finished his share of the work before his departure, but it had, of necessity, to be somewhat hurriedly done, and both authors felt that some further scrutiny was desirable before venturing on publication. Through the courtesy of Professor H. Lecomte, Director of the Paris Herbarium, the types of the numerous new species of Rhododendron described by the late Mr. A. Franchet were transmitted to Kew for purposes of comparison; but Mr. Hemsley found himself unable during the last two years of his official life to make further comparisons, and complete his share of the task. In the meantime, however, Mr. J. Hutchinson had made a rough classification of the Chinese species, named a number of previously undetermined specimens, and found reason to question the validity of some of the new species proposed by Messrs. Hemsley and Wilson.

During the past year Mr. Hemsley has re-examined most of the specimens and has adopted many of Mr. Hutchinson's suggestions. Even yet something doubtless remains to be done before a satisfactory classification of the species can be offered. Some of those proposed as new are based on slender characters, and it is to be suspected that one or two may be natural hybrids. Unfortunately Mr. Wilson, on his return from his third journey with further field experience, found himself unable, owing to the pressure of other work, to look through the material again with $\mathrm{Mr}$. Hemsley before

(16106-6a.) Wt. 92-428. 1375. 4/10. D \& S. 
leaving for America, so that in many instances Mr. Hemsley alone is responsible for the final determinations here published.

The following sketch of the Rhododendron vegetation of China was written by Mr. Wilson before his last journey, and he has had no opportunity of revising it; but the points dealt with are probably not susceptible of important modification. The original plan of the authors was limited to the publication of the new species in Mr. Wilson's collections, but the opportunity now offered has been taken to give determinations of all the specimens received at Kew since the appearance in 1889 of the enumeration of the species then known, published in the Journal of the Linnean Society of London, vol. xxvi. In doing this the numbers of the various collectors are cited, so that this addition may be of use to other institutions possessing sets of these dried plants.

A few modifications in the spelling of place-names have been admitted, the following being the most important:-Tatienlu for Tatsienlu; Szechuan for Szechuen; Omi for Omei, and Yangtsze for Yangtze.

\section{The Distribution of Rhododendrons in China.}

One of the outstanding features of recent botanical exploration in China is the wealth of Rhododendrons discovered. Up to the present time, and exclusive of the new species hereinafter described, no fewer than 134 species are known to occur in China proper : indeed, Rhododendron is one of the largest genera recorded from China.

The Index Kewensis enumerates to date (December, 1906) some 305 species of Rhododendron distributed as follows :-China proper, 134 species; Malaya, 62 species ; British India, 46 species ; Japan and Corea, 28 species ; North America, 19 species; Orient, six species; Europe, four species; Siberia, three species ; Arctic regions, two species; and Australia, one species. From Africa and from Central and South America the genus is absent. The above figures show conclusively that the headquarters of the genus is China. Now, a cursory knowledge of the distribution of the Chinese Rhododendrons is sufficient to prove that the centre of the greatest concentration of species is the wild and rugged region of the China-Tibet borderland-which region is a continuation of the Himalayas. The optimum is somewhere between Mupine, long. $102^{\circ} 30^{\prime}$, lat. $31^{\circ}$ about, and Tali, long. $100^{\circ}$, lat. $25^{\circ} 50^{\prime}$ about. North of Mupine, Rhododendrons rapidly decrease in numbers, and in the extreme north-west of Szechuan and in Kansu, comparatively few species occur. The same obtains in the country south of 'I'ali.

In China, the genus Rhododendron extends from sea-level to the limits of ligneous vegetation. There is no heather (Calluna or Erica) in China, and its place on the alpine moorlands is taken by dwarf, small-leaved Rhododendrons such as $R$. fastigiatum, $\boldsymbol{R}$. nigro-punctatum, $R$. intricatum, and $R$. blepharocalyic.

The low-level species, such as $R$. indicum and $R$. sinense, are abundant on scrub-clad hills, but whilst the former extends from 
the east to the west of the country, the latter scarcely occurs west of long. $112^{\circ}$. In Central and Western China, with the exception of the above two species and $R$. Mariesii, no Rhododendron occurs below $4000 \mathrm{ft}$. Above this altitude they occur in woods and forests in increasing numbers, reaching their optimum at about $11,000 \mathrm{ft}$. In the regions traversed by me, $15,500 \mathrm{ft}$. was the altitudinal limit of the genus. Farther west, however, it is somewhat higher. Rhododendrons are social plants, and at certain altitudes form immense thickets. At low levels, miles of the hillsides often are ablaze with the scarlet $R$. indicum. Up to $9000 \mathrm{ft}$. the Rhododendrons occur in constantly increasing numbers, in company with mixed dicotyledonous trees and shrubs and conifers. Above $9000 \mathrm{ft}$. they form the predominant shrubby vegetation, either as undergrowth in the conifer forests or above the tree limit, where they form impenetrable thickets. In late May and June these areas present a scene of indescribable beauty.

In stature, Chinese Rhododendrons vary from tiny plants six inches high ( $\boldsymbol{R}$. nigro-punctatum) to trees 40 feet high $(\boldsymbol{R}$. calophytum). But omitting extremes, they are as a rule bushes from 6-20 feet high and as much in diameter.

Epiphytic species are rare, and only two, $R$. dendrocharis and $\boldsymbol{R}$. moupinense, have been met with. The first-named is very common on coniferous trees, especially on Abies Fargesii and Tsuga yunnanensis. $R$. moupinense occurs on evergreen oaks and dicotyledonous trees generally. Both species are dwarf and twiggy, and at a distance are suggestive of species of Loranthus. But whilst true epiphytes are rare in the depths of coniferous forests, a large percentage of the Rhododendron bushes occur growing on the rotting trunks of fallen forest giants.

In colour the Chinese Rhododendrons range from the purest white, the clearest and richest yellow, the varying shades of red, the deepest and richest shades of crimson, to the darkest purple. In size the flowers may vary in diameter from less than a third of an inch ( $R$. anthopogonoides) to three inches, $R$. excellens. With rare exceptions ( $R$. sinense, $R$. indirum, R. micranthum, $R$. Mariesii, and possibly a few others) all the species are remarkably local, whether in longitudinal, latitudinal or altitudinal range. With the exception of $\boldsymbol{R}$. stamineum none of the Hupeh species occur in western Szechuan. Very few of Père Delavay's Y unnan species are to be found even in South Szechuan although the regions are contiguous. The species collected by Père Bodinier in Kweichau Province are nearly all different from those collected in the adjoining provinces of Hupeh, Yunnan and Szechuan. The last collections to reach Kew from China are one made by Père Monbeig near Tsekou, a town on the Mekong river in the extreme north-west of Yunnan, and another from South-Western China, composed of very fine specimens, made by Mr. G. Forrest and presented by Dr. Bayley Balfour, F.R.S. Of the seventeen species of Rhododendron in Père Monbeig's collection, nearly half are new. With one exception all are distinct from those collected by me in a district two degrees of longitude east and two degrees of latitude north of 'T'sekou. Père Delavay approached to within 60 miles of Tsekou, yet only two of the species in Père Monbeig's collection were 
met with by him. The altitudinal limit of any one species is welldefined, and within this limit a species monopolises its own particular region. This phenomenon is extremely interesting and often gives rise to distinct belts of colour. R. Przewalskii ( $R$. kialense) attains the highest altitudinal range (14,500 ft.) of any of the large-leaved species.

The Chinese Rhododendrons form their own peculiar groups, some of which are extremely difficult to deal with taxonomically. It may be that these groups represent several or few distinct species, or possibly one or more variable species in which the individuals intercross and give rise to numerous intermediate forms. Many of the species hitherto described can only be regarded as provisional, and when our knowledge of these Chinese Rhododendrons is more complete a general revision will be necessary. A goodly number of them are now in cultivation in this country, and these should materially assist in elucidating some of the many problems necessarily connected with so large and unwieldy a genus.

The genus is difficult owing to the fact that good and obvious distinguishing characters are scarce; the calyx, capsule, tomentum and stamens perhaps yielding the chief diagnostic marks. Vegetative shoots, though very necessary, are most certainly insufficient in themselves. For this reason, and when the vast number of described species is borne in mind, it is not desirable to follow the example set in connection with two recently recognised species, $R$. platypodon and $R$. coeloneuron, and be content to base the recognition of new forms on the examination of vegetative shoots. The colloquial names given to these species-shan p' i-pa and chin p' i-pa shu-do not admit of practical application because the first is a general name with the Chinese for all the large-leaved Rhododendrons, whilst "chin" prefixed to the second name (though it might possibly mean among other things "clear" or "gold") signifies in all probability nothing more than green. Such vernacular appellations are commonly manufactured on the spur of the moment by natives of Eastern countries in response to the demand for a name.

The collection of Rhododendrons made by me in China consists of some 63 species. Seeds of practically all were sent home, and with very few exceptions the species are in cultivation with Messrs. J. Veitch \& Son, in their Coombe Wood Nursery. From the altitude and latitude in which they occur, it is highly probable that nearly all will prove hardy and amenable to cultivation in this country.

The pleasure derived from working out this collection has been heightened by the fact of its affording the collector an opportunity of commemorating the names of various people to whom he had been indebted for hospitality and assistance in some form or other during his wanderings in China.

The use of nearly all of the late Mr. Franchet's types, for which Kew is indebted to the kindness of Mr. Lecomte, Director of the Paris collection, has rendered the task of determination very much easier than would otherwise have been possible.-E. H. W. 


\section{III.-Enumerations and Descriptions.}

\section{EURHODODENDron.}

\section{I.-Leaves not lepidote; usually densely tomentose beneath.*}

Rhododendron taliense, Franch. in Bull. Soc. Bot. France, xxxiii. 232 ; Hemsl. in Journ. Linn. Soc., xxvi. 31.

Szechuan. Wilson, 3953, 3957, 3968, 3970.

We at first thought we could separate the specimens bearing the above numbers into three species, but the differences, chiefly in degree of hairiness of the petioles, pedicels and filaments, are insufficient. All the specimens agree in having a glabrous ovary.

Rhododendron Wasonii, Hemsl. et E. H.Wils.; inter species foliis valde coriaceis subtus dense tomentosis (in siccis rufis) $R$. taliensi proxima, differt foliis suboppositis, floribus majoribus longius pedicellatis et ovario densissime furfuraceo-tomentoso. An varietas tantum $R$. taliensis ?-W. B. H.

Bush about $1 \mathrm{~m}$. high ; branches thick, straight, hoary when young. Leaves scattered, sub-opposite, broadly-lanceolate or ovate, excluding the petioles 6-7 $\mathrm{cm}$. long, 2.5-4 cm. broad, acute or cuspidate, base broadly cuneate or slightly auricled, glabrescent and slightly wrinkled above, densely clothed with reddish-brown felt beneath; primary and secondary veins somewhat immersed on upper surface ; petioles thick, 5-8 mm. long, felted. Buds elongate ; scales about $1 \mathrm{~cm}$. long, narrowly-oblong, acuminate or ovate, aristate. Flowers about six, in short corymbose racemes; pink or creamy-white, $4-5 \mathrm{~cm}$. across ; rachis sparsely pubescent; pedicels stout, erect or nearly so, $1 \cdot 5-2 \cdot 5 \mathrm{~cm}$. long, floccose. Calyx minute, oblique, annular, obscurely 5-toothed, densely' floccose. Corolla broadly campanulate, slightly narrowed to base, 5-lobed, glabrous ; lobes erect-spreading, rounded or emarginate. Stamens 10, included ; filaments unequal, longest under $2 \mathrm{~cm}$. in length, villous in the lower half. Pistil over-topping the stamens ; ovary 4-5 mm. long, furrowed, densely villous, hairs brownish. Capsule about $1 \mathrm{~cm}$. long, $4 \mathrm{~mm}$. broad, furrowed, densely clothed with loose brown felt ; calyx-teeth somewhat enlarged in fruit, obtuse.

SzechuAn. Near Tatienlu on rocks in coniferous forests, alt. 2800-3000 m., Wilson, 3955, 3956, 3969, 3969A.

No. 3956 has more villous filaments and a rather more elongated inflorescence than 3955 , and 3969 has somewhat smaller flowers. Named in compliment to Mr. Cathcart Wason, R.N., in 1903-04 Lieut.-Commander of H.M.S. "Woodlark" at Chungking, on the upper Yangtsze River, as a mark of appreciation of his kind offices.E. H. W.

Rhododendron Faberii, Hemsl. in Journ. Linn. Soc. xxvi. 22. R. Prattii, Franch. in Journ. de Bot. ix. 389.

Szechuan. Pratt, 58, 89; Wilson, 3958, 3958a, 3959, 3960, 3961,5 l 42 .

This belongs to a group of species, or varieties, having very thick leaves densely felted on the under surface, similar to those of $\boldsymbol{R}$. taliense, but differing from the latter in having a well-developed petaloid calyx.

\footnotetext{
* As arranged in the Kew Herbarium by Mr. J. Hutchinson.
} 
Rhododendron Brettii, Hemsl. et E. H. Wils.; ex affinitate R. Faberii, a quo differt foliis praeter costam subtus glabris, corymbis multifloris et floribus majoribus longius pedunculatis.W. B. H.

Bush about $3 \mathrm{~m}$. high ; branches thick, densely clothed with rufous tomentum which persists for two or more years. Leaves crowded, oblong, lanceolate, excluding petiole $9-12 \mathrm{~cm}$. long, 3-4 cm. broad, cuspidate or shortly acuminate, base slightly auricled; upper surface dark green, glabrous, somewhat wrinkled, lower surface pallid, glabrous; midrib immersed above, often felted at base, very prominent below, densely rufously tomentose, especially in lower half; petioles stout, $1-2 \mathrm{~cm}$. long, rufously tomentose. Flowers twelve or more, subumbellate, multi-bracteate, pink with a dark red blotch, 5-6 $\mathrm{cm}$. across ; pedicel rather slender, spreading, 2.5-3 cm. long, densely glandular and sparsely pilose ; bracts crowded amongst leaves and flowers, persistent, variable; outer thick, more or less subulate, flattened at base, $2-2.5 \mathrm{~cm}$. long, rufously tomentose ; inner membraneous, spathulate or ovatespathulate, $2-3.5 \mathrm{~cm}$. long, rounded or obtuse, silkily pubescent. Calyx petaloid, 5-lobed, glandular and pilose, tube nearly obsolete, lobes oblong, 10-13 mm. long, 3-4 mm. broad, acute or obtuse, erect. Corolla widely-campanulate, narrowed to base, 5-lobed ; tube pubescent within at base ; lobes erect-spreading, broad, deeply emarginate. Stamens about 10, included ; filaments unequal, 1.5-3 cm. long, villous in lower half. Pistil over-topping stamens; ovary about $4 \mathrm{~mm}$. long, glandular and sparsely pilose ; glands stalked; style with stalked glands in lower half; stigma very large. Capsule $1 \cdot 5-2 \mathrm{~cm}$. long, $8 \mathrm{~mm}$. broad, furrowed, clothed with shortly-stalked glands ; calyx lobes appressed to capsule.

SzechuaN. Neighbourhood of Tatienlu, at 2750-3000 m. above sea-level, Wilson 3973 .

A very striking and handsome species, not common. Named in commemoration of the kind hospitality and assistance given by Mr. H. J. Brett, of H.B.M.'s Chinese Consular Service, who was stationed at Chentu, Szechuan, in 1904.-E. H. W.

Rhododendron bullatum, Franch, in Bull. Soc. Bot. France xxxiv. 281 ; Hemsl. in Journ. Linn. Soc. xxvi. 20.

Yunnan. Monbeig, 10 ; G. Forrest, 4141.

Rhododendron floccigerum, Franch. in Journ. de Bot. xii. 259.

Yunnan. Tsekou, Monleig, 8.

Rhododendron sanguineum, Franch. in Journ. de Bot. xii. 259.

Yunnas. Tsekou, Monbeig, 13, 14.

Rhododendron Bureavii, Franch. in Bull. Soc. Bot. France xxxiv. 281 ; Hemsl. in Journ. Linn. Soc. xxvi. 21.

Szechuan. Wilson, 3954. Yunnan. G, Forrest, 506.

Rhododendron haematodes, Franch. in Bull. Soc. Bot. France xxxiii. 232 ; Hemsl. in Journ. Linn. Soc. xxvi. 24.

YunNan. G. Forrest, 4130.

Rhododendron floribundum, Franch. in Bull. Soc. Bot. France xxxiii. 232.

Szechuan. Wilson, 3967 . 
Rhododendron Falconeri, Hook. f. Rhod. Sik. Himal. 11, t. 10 ; Bot. Mag. t. 4924.

Yunnan. Mountains north of Mengtsze at 3000 m., A. Henry, 9448 ; Great Black Mountain range at 3000 m., W. Hancock, 439.

$\mathrm{Mr}$. Wilson was disposed to regard the Chinese specimens as specifically different from the Indian $R$. Falconeri, distinguished by the calyx, the constantly 7-lobed corolla and other slight differences, but further comparison of all the specimens at Kew is against this conclusion. He describes it as a tree about 6 metres high with leaves from 15-36 centimetres long and clusters of 12-20 pale yellow or primrose flowers.-W. B. H.

Rhododendron Wiltonii, Hemsl. et E. H. Wils.; species elegans $R$. floribundo proxima, $a b$ eo tamen differt foliis minoribus obovatis vel oblanceolatis supra nitidis, genitaliis omnino inclusis et filamentis infra medium puberulis.-W. B. H.

Bush, 1.5-2.5 m. high ; branches stout, more or less pubescent, often clothed with dark-coloured persistent bracts; bark rough, scaly. Leaves crowded, very coriaceous, oblong-cbovate, excluding petiole $5-8 \mathrm{~cm}$. long, $2-3.5 \mathrm{~cm}$. broad, apiculate or cuspidate, base narrowed to the petiole, shining green, rugose above, heavily clothed with loose brown felt beneath; midrib and secondary veins impressed above, much raised below ; petioles $1 \cdot 25-2 \mathrm{~cm}$. long, more or less felted. Flower's six or more, surrounded by a cluster of bracts, sub-umbellate, pink with red spots, $3-4 \mathrm{~cm}$. across ; pedicels stout, spreading, $1 \cdot 5-2.5 \mathrm{~cm}$. long, floccose; bracts numerous, clustered among the flowers and leaves, linear-oblong-acuminate, spathulate or orbicular, floccose or glabrescent, many persisting for a year or more. Calyx minute, annular, obscurely 5-toothed, floccose ; teeth obtuse. Corolla widely campanulate, 5-lobed, glabrous ; lobes short, slightly spreading, rounded or emarginate. Stamens about 10, included ; filaments unequal, 1-1.5 cm. long, dilated and somewhat villous below the middle. Pistil overtopping stamens ; ovary 4-5 mm. long, very floccose ; stigma small. Capsule cylindric, $1 \cdot 5-2 \cdot 5 \mathrm{~cm}$. long, 4-6 $\mathrm{mm}$. broad, furrowed, clothed with rufous-brown, floccose tomentum; calyx-teeth in fruit slightly enlarged, ovate, obtuse, appressed to capsule. 3952 .

SzechuAN. In thin woods at $3300 \mathrm{~m}$. above sea-level, Wilson,

A very interesting species belonging to a small group having shining, bullate or rugose leaves, represented heretofore in China by $\boldsymbol{R}$. bullatum, Franch., and $\boldsymbol{R}$. detersile, Franch. The firstnamed is a native of western Yunnan and has ovate, very bullate leaves, and an enormous calyx. $R$. detersile is a native of northeast Szechuan, and has shortly-stalked, verruculose leaves, subauriculate at the base, with a calyx intermediate between that of $\boldsymbol{R}$. bullatum and that of $\boldsymbol{R}$. Wiltonii.

Named in compliment to Mr. E. C. Wilton, C.M.G., of H.B.M.'s Chinese Consular Service, in 1900 Acting Consul at Ichang, as a mark of appreciation of numerous kind offices during that troublous year.-E. H. W.

Rhododendron strigillosum, Franch. in Bull. Soc. Bot. France xxxiii. 232.

Szechuan. A. Henry, 8872 ; Pratt, 311 ; Wilson, 3974. 
Rhododendron auriculatum, Hemsl. in Journ. Linn. Soc. xxvi. 20. Hupen. A. Henry, 7562, 7725 ; Wilson, 1467.

Rhododendron adenopodum, Franch. in Journ. de Bot. ix. 391. HUPEH. Wilson, 1161.

Rhododendron Fordii, Hemsl. in Kev Bull. 1894, 5.

KWAngtung. Ford.

Rhododendron formosanum, Hemsl. in Kew Bull. 1895, 183.

Formosa. A. Henry, 1976.

Rhododendron Przewalskii, Maxim. in Mel. Biol. i. 771 ; Hemsl. in Journ. Linn. Soc. xxvi. 29 . R. kialense, Franch. in Journ. de Bot. ix. 392.

Szechuan. Wilson, 3968.

Rhododendron Delavayi, Franch. in Bull. Soc. Bot. France xxxiii. 231 ; Hemsl. in Journ. Linn. Soc. xxvi. 22 ; Bot. Mag. t. 8137.

Yunnan. Hancock, 158 ; A. Henry, 10,983, 10,983A, 11,330 ; G. Forrest, 4093.

II. Leaves not lepidote; glabrous below.

a Leaves usually broad at the base; sometimes cordate. 169.

Rhododendron orbiculare, Decne in Flore des Serres xxii. (1877),

Szechuan. Pratt, 325 ; A. Henry, 8873 ; Wilson, 3951.

Rhododendron Souliei, Franch. in Journ. de Bot. ix. 393.

Szechuan. Wilson, 3971.

Rhododendron chartophyllum, Franch. in Journ. de Bot. ix. 398.

Yunnan. G. Forrest, 2030.

Rhododendron selense, Franch. in Journ. de Bot. xii. 257.

YUnNan. Monbeig, 12.

Rhododendron Sheltonae, Hemsl. et E. H. Wils. ; species ex affinitate $R$. selensis, a quo differt foliis subtus minus conspicue venosis pallidis, staminibus glabris et ovario styloque per totam longitudinem glanduloso.-W. B. H.

Bush, l-2 m. high; branches short ; bark grey and rough. Leaves elliptic-ovate, excluding petiole $6-8 \mathrm{~cm}$. long, 3-4 cm. broad, apiculate, base oblique or rounded, glabrous, dull green above, very pallid below ; petioles stout, $1 \cdot 5-2 \mathrm{~cm}$. long. Buds broadly ovoid, obtuse; scales short, broad, rounded, apiculate, ciliolate. Flower's eight or more, sub-umbellate, pink, $4-5.5 \mathrm{~cm}$. across ; pedicels 0.75-2 cm. long, spreading, sparsely glandular. Calyx annular, oblique, 7-toothed, glandular; teeth minute, unequal, ovate, acute, often with a tiny apical tuft of white hairs, ciliolately glandular. Corolla widely campanulate, narrowed to base, 7-lobed ; lobes spreading, usually emarginate. Stamens 12 or more, included ; filaments $1 \cdot \tilde{0}-2 \mathrm{~cm}$. long, straight, glabrous. Pistil as long as corolla, glandular ; ovary 6-8 mm. long; style slightly thickened above the middle. Capsule cylindric, 1.5-2 cm. long, $5 \mathrm{~mm}$. broad, glandular.

Szechcan. Neighbourhood of Tatienlu, in open country at 2750-300ก m. above sea-level, Wilson, 3977 . 
A very neat species, common on scrub-clad mountains near Tatienlu.

Named in compliment to Mrs. Shelton, wife of Dr. Shelton, Missionary at 'Tatienlu, to both of whom I am indebted for kind hospitality during 1904.-E. H. W.

Rhododendron Fargesii, Franch. in Journ. de Bot. ix. 390.

HuPEH. Wilson, 1877. YunNan. Wilson, 3972.

Rhododendron decorum, Franch. in Bull. Soc. Bot. France xxxiii. 230 ; Hemsl. in Journ. Linn. Soc. xxvi. 22.

Yunnas. Hancock, 157 ; A. Henry. 9155A ; G. Forrest, $2119,2253$.

$\boldsymbol{R}$. decorum belongs to a small group having large, corymbosely racemose flowers, and is closely allied to the eastern $\boldsymbol{R}$. Fortunei, Lindl., differing in having white flowers with bearded filaments. Forrest describes the flowers as fragrant, white with green markings. Perhaps a variety of $\boldsymbol{R}$. Fortunei, but in the absence of fuller material we do not venture to reduce it.

Rhododendron pachytrichum, Franch. in Bull. Soc. Bot. France xxxiii. 231.

Szechuan. Wilson, 3976, 3976 A.

Rhododendron maculiferum, Franch. in Journ. de Bot. ix. 393.

Hupen. Wilson, 1878, 6949.

Rhododendron Fortunei, Lindl. in Gard. Chron., 1859, 868 ; Maxim. Rhod. As. Or. 21 ; Bot. Mag. t. 5596 ; Hemsl. in Journ. Linn. Soc. xxvi. 23.

Kiangsi. Bullock. Huper. A. Henry, 5354; Wilson, 609.

Mr. Wilson was of opinion that his 609 represented a distinct species, but on further examination I am unable to accept this view. In the Index Kewensis the authorship of $R$. Fortunei is attributed, in square brackets, to $\mathrm{T}$. Moore, but we have not found any evidence of the correctness of this record.

Mr. Consul Cooper collected R. Fortunei in 1884, on the Tientai Mountain, Chekiang, where, he notes, there were magnificent groves of it ; Mr. T. L. Bullock collected it at Kiukiang, Kiangsi, in 1892. Writing of this species in the Gardeners' Chronicle, in 1859, Fortune states that $\boldsymbol{R}$. Championae, Hook., was the only other species known, at that date, to inhabit China. It should be mentioned, however, that he did not include the species belonging to the section Azalea.

The specimens from Hupeh are rather more glandular than the eastern ones, and the leaves are mostly broadest above the middle.W. B. H.

Rhododendron Hemsleyanum, E. H. Wils.; species distincta e grege $\boldsymbol{R}$. Fortunei, Lindl., floribus grandibus, racemoso-corymbosis, ab omnibus speciebus hujus gregis foliis amplissimis basi alte auriculatis facile distinguitur.-W. B. H.

Bush, about $6 \mathrm{~m}$. high ; branches thick, glabrous. Leaves very coriaceous, oblong, excluding petioles $15-20 \mathrm{~cm}$. long, 8-10 cm. broad, rounded, base deeply auricled, glabrous, dark shining green above, pallid below, primary and secondary veins prominent on both surfaces ; petioles very thick, Heshy, $5 \mathrm{~cm}$. long. Flowers ten or more in corymbose racemes, white, 6-8 cm. across ; rachis thick, 
reddish, about $7 \mathrm{~cm}$. long, glandular and sparsely pilose ; pedicels erect-spreading, 3-4 cm. long, pilose, with numerous, scattered gland-tipped hairs. Calyw nearly obsolete, annular. Corolla widely campanulate, narrowed to base, prominently veined, 7-lobed; lobes spreading, broad, rounded. Stamens 10, included; filaments slender, about $3 \mathrm{~cm}$. long, very slightly dilated at base, glabrous ; anthers oblong, 4-5 mm. long. Pisil overtopping stamens, clothed with shortly-stalked glands; style thickened and reddish above the middle ; stigma very large, flattened. Fruit not seen.

Szechuan. Mount Omi, Wilson, 5138.

A remarkable, fine and distinct Rhododendron only met with on Mount Omi and very rare even there; not closely allied to any known species but nearest $R$. auriculatum, Hemsl., which has much more shortly auricled leaves more or less tomentose below; coarsely glandular-hairy petioles and a differently shaped corolla somewhat hairy outside. The only real points of agreement are the large flowers and auricled leaves in both species. $R$. Hemsleyanum is one of the most handsome and one of the largest growing of all Chinese Rhododendrons.--E. H. W.

Rhododendron Houlstonii, Hemsl. et L. H. Wils. ; species ex affinitate $\boldsymbol{R}$. discoloris et $\boldsymbol{R}$. Fortunei a quibus differt foliis oblanceolato-oblongis basi cuneatis, pedicellis glabris et ovario apice glandulis longe stipitatis ornato.-W. B. H.

Bush, 1·5-4 m. high ; branches stout, straight. Leaves oblongobovate or oblong, excluding petioles $8-13 \mathrm{~cm}$. long, $3-5 \mathrm{~cm}$. broad, cuspidate ; base more or less cuneate, rarely oblique ; pallid below ; midrib slightly immersed above, brownish and very prominent below ; petioles stout, $1 \cdot 5-3 \mathrm{~cm}$. long. Flowers eight or more, in lax cormybose racemes, flesh-pink, 6-8 $\mathrm{cm}$. across; rachis glaucescent; pedicels erect-spreading, $1.5-3 \mathrm{~cm}$. long, more or less glandular. Calyx oblique, annular, obscurely toothed. Corolla widely campanulate, narrowed to base, 7-lobed, lobes erect-spreading, rounded or truncate. Stamens about 12, included; filaments unequal, 1.5-2.5 cm. long, slightly curved, glabrous. Pistil as long as corolla ; ovary glandular in the lower, bearded in the upper, half; style stout, sparsely glandular, bearded near base. Capsule bluishpurple, cylindric, $2.5 \mathrm{~cm}$. long, $7 \mathrm{~mm}$. broad, rarely glandular.

Western HuPeh. In woods, Wilson, 312, 2154 in part.

Named in compliment to Mr. G. Houlston, of the Chinese Imperial Maritime Customs Service, my companion on many a delightful ramble in the Ichang neighbourhood.-E. H. W.

Rhododendron Spooneri, Hemsl. et E. H. Wils.; ex affinitate $\boldsymbol{R}$. Fortunei et forsan ejus varietas floribus minoribus, pedicellis crassis glabris et filamentis puberulis.-W. B. H.

Bush, 1-3 m. high ; branches stout, straight. Ieaves coriaceous, oblong-lanceolate or oblong, often broadest above the middle, excluding petioles $6-13 \mathrm{~cm}$. long, $1 \cdot 5-5.5 \mathrm{~cm}$. broad, rounded, apiculate, base cuneate or sub-auricled, glaucous or very pallid below ; petioles thick, $1-1.5 \mathrm{~cm}$. long. Flowers ten or more, in lax corymbose racemes, white or pale pink, 5-7 cm. across ; pedicels fleshy, erect-spreading or spreading, 2-4 cm. long, very glandular when young, speedily becoming quite glabrous; bracts oblong, $2-2.5 \mathrm{~cm}$. long, clothed with white, silky, appressed hairs on both 
surfaces. Calyx oblique, saucer-shaped, glabrous. Coroll $\mu$ widely campanulate, much narrowed to base, 7-lobed; lobes rounded or truncate. Stamens about 16, included; filaments $2-2.5 \mathrm{~cm}$. long, sparsely glandular and villous in the lower half. Pistil equalling corolla, clothed with scattered, shortly-stalked glands; style stout, cylindric ; stigma large. Capsule $4 \mathrm{~cm}$. long, $1.5 \mathrm{~cm}$. broad furrowed, slightly curved, brownish-purple.

Szechuan. Neighbourhoad of Tatienlu, on scrub-clad moun tains 2650-3650 m. above sea-level, Wilson, 3975. Yunnan. Tsekou, Monbeig.

Père Monbeig's specimens have the leaves broader and subauricled at the base, less glaucous below; the corolla-tube slightly hairy inside and the filaments more or less villous. In spite of these slight differences there can scarcely be any question as to their being conspecific with those from Yunnan.

Named in compliment to my friend Mr. H. Spooner, who very largely assisted in making up my collections into sets for disposal to different herbaria.-E. H. W.

$\beta$ Leaves narrowed towards the base.

Rhododendron Vialii, Franch. in Journ. de Bot. ix. 398.

Yunnan. A. Henry, 11,563A, 13,271.

Rhododendron brevistylum, Franch. in Journ. de Bot. xii. 261.

Yunnan. G. Forrest, 4162 .

Rhododendron hypoglaucum, Hemsl. in Journ. I.inn. Soc. xxvi. 25.

Szechuan. Wilson, 5137. HuPEH. Wilson, 311.

Rhododendron neriiflorum, Franch. in Bull Soc. Bot. France xxxiii. 230 ; Hemsl. in Journ. Linn. Soc. xxvi. 28.

YunNan. G. Forrest, 4144, 4164.

Rhododendron argyrophyllum, Franch. in Bull. Soc. Bot. France xxxiii. 231.

Szechuan. Wilson, 3962, 3963, 3966, 5137a.

Wilson's 3966 differs from the other specimens in having glabrous filaments, and his $3962 \mathrm{~A}$, which must also be referred to this species, has much less hairy filaments and otherwise differs slightly from the type.

Rhododendron Ririei, Hemsl. et E. H. Wils.; species distincta esquamosa, ramis elongatis viridibus, foliis sparsis supra viridibus opacis subtus pallidioribus et floribus racemosis. - W. B. H.

Bush, about $6 \mathrm{~m}$. high ; branches long, straight, with greyishgreen bark when young. Leaves scattered, lanceolate or oblonglanceolate, very rarely broadest above the middle, excluding petiole 10-15 cm. long, 3-5.5 cm. broad, shortly acuminate, base narrowed, cuneate, pale green glabrous above, grey below, midrib slightly immersed above, prominent below; petioles $1.5-2 \mathrm{~cm}$. long, glabrous. Buds ovoid, acute; scales broadly-ovate, some ciliolate, lower acute, upper rounded. Flowers about ten in short corymbose racemes, white, about $5 \mathrm{~cm}$. across ; pedicels spreading, very stout, 1.5-2 cm. long, sparsely pubescent. Calyx oblique, annular, obscurely 5-toothed. Corolla widely campanulate, 5-lobed; lobes erect-spreading, broad. Stamens included; filaments filiform, glabrous? Pistil reaching to corolla-mouth; ovary about $1 \mathrm{~cm}$. long, densely clothed with short grey felt; style very stout, 
cylindric, reddish. Capsule large, cylindric, ahout $3 \mathrm{~cm}$. long, $1 \mathrm{~cm}$. broad, with shallow channels, greyish.

Szechuan. Mount Omi, Wilson, 5139.

Our material consists of two sheets ; one with one old flower and very young fruit ; the other with ripe fruit. The very large fruits afford a marked distinction from other members of the group to which this belongs, and in consequence we do not hesitate to describe it.

Named in compliment to the Rev. B. Ririe, of the China Inland Mission, Kiating, Western Szechuan, who rendered me considerable assistance during my second journey in China.-E. H. W.

Rhododendron discolor, Franch. in Journ de Bot. ix. 391.

Szechuan. Wilson, 1077. Hupeh. Wilson, 1077.

Rhododendron calophytum, Franch. in Bull. Soc. Bot. France xxxiii. 230.

Szechuax. Wilson, 3979.

Rhododendron sutchuenense, Franch. in .Journ. de Bot. ix. 392.

Western Hupeh. Wilson, 17, 2537, 5285, 6914.

Rhododendron Watsonii, Hemsl. et E. H. Wils.; species $R$. sutchuenensi simillima differt imprimis foliis subsessilibus, floribus minoribus longius pedicellatis et fructu minore curvato.-W. B. H.

Bush, $2 \cdot 6 \mathrm{~m}$. high ; branches very thick, glabrous. Leaves clustered at ends of shoots, very shortly petiolate, obovate or oblong-obovate, excluding petiole $15-20 \mathrm{~cm}$. long, $5-7 \mathrm{~cm}$. broad, shortly acuminate, base narrowed to petiole, dark green, glabrous, somewhat wrinkled above, clothed with short, dense, grey felt beneath; midrib very large and broad, channelled above, very much raised below, secondary veins prominent on both surfaces ; petioles thick, broad, winged, 0.5-1 cm. long. Buds globose; scales short, orbicular, concave, slightly pubescent on inner surface. Flowers twelve or more in short corymbose racemes, white with red blotch, 4-5 $\mathrm{cm}$. across ; rachis short, very thick, sparsely pubescent ; pedicels spreading or erect-spreading, $2-3.5 \mathrm{~cm}$. long, glabrous or nearly so. Calyx oblique, annular, 7-toothed; teeth unequal, largest 1-2 mm. long, ovate, acute or rounded. Corolla short, broadly campanulate, 7-lobed, glabrous ; lobes elliptic, more or less spreading, rounded or emarginate. Stamens about 14, included ; filaments unequal in length, 2-3 cm. long, sparsely pubescent in lower half. Pistil equalling in length the longest stamens, ovary about $8 \mathrm{~mm}$. long, slightly puberulous, furrowed; stigma small, flattened. Capsule cylindric, often curred, about $3 \mathrm{~cm}$. long, 8-10 mm. broad, woody.

SzechuAN. In thin coniferous forests, at $3300-3800 \mathrm{~m}$. above sea-level, Wilson, 3964.

Named in compliment to my friend and travelling eompanion, Mr. W. C. Haines-Watson, of the Chinese Imperial Maritime Customs Service.-E. H. W.

Rhododendron irroratum, Franch. in Bull. Soc. Bot. France xxxiv. 280 ; Hemsl in Journ. Linm. Soc. xxvi. 26 ; Bot. Mag. t. 7371.

Yunnan. A. Herry, 10,275, 10,301, 10,853, 11,066, 11,067, 11,067в ; W. Hancock, 179 ; G. Forrest, 2043, 2058, 4146 ; Monbeig, 4. 
Dr. A. Henry's 10,853 from Yunnan and Père T. Monbeig's n. 4, from the same province, differ from typical $R$. irroratum in the filaments and ovary being glabrous or nearly so.

Rhododendron insigne, Hemsl. et $\boldsymbol{E}$. $\boldsymbol{H}$. Wils. ; inter species affines $\boldsymbol{R}$. irrorato proximum et simillimum, ab eo tamen differt foliis sparsis margine haud undulatis et floribus distincte racemosis longe pedicellatis.-W. B. H.

Bush, $1 \cdot 6 \mathrm{~m}$. high ; branches thick, straight. Leaves very coriaceous, often sub-opposite, lanceolate-oblong, very rarely broadest above the middle, excluding petiole 9-13 $\mathrm{cm}$. long, 3-5 $\mathrm{cm}$. broad, shortly acuminate, base cuneate, margins reflexed, shining green above, uniformly clothed with dense, short, grey felt below ; midrib immersed above, raised below, secondary veins prominent on both surfaces ; petioles thick, 1-2 cm. long, flattened above. Bud-scales oblong or oblong-spathulate, $1 \cdot 5-3 \mathrm{~cm}$. long, acuminate, fleshy, brown, lowest filiform, flattened at base, upper ciliolate, more or less pubescent on inner surface. Flowers eight or more, in short lax corymbose racemes, pale or deep pink, 3-5 cm. across, bracteate ; bracts oblong-lanceolate or oblong, lowest filiform, $1 \cdot 5-2 \mathrm{~cm}$. long, 7-10 mm. broad, fleshy, brown, tomentose without, often pubescent within ; pedicels spreading or erect-spreading, 2-4 cm. long, reddish, sparsely pubescent. Calyx annular, sometimes truncately 5-toothed; teeth short, broad, rounded, pubescent. Corolla wide campanulate, 5-lobed ; lobes erect-spreading, rounded or emarginate. Stamens 14 or more, included ; filaments $1 \cdot 5-2 \cdot 5 \mathrm{~cm}$. long, villous in lower half. Pistil equal to the corolla in length ; ovary $6-8 \mathrm{~mm}$. long, densely clothed with a white relvety pubescence; style stout, glabrous, reddish ; stigma dark-coloured, flattened. Fruit not seen.

Szechuan. Mount Wa, at 2300-3000 m. above sea-level, Wilson, 3965 ; Pratt, 349 ; A. Henry, 8859.

An exceedingly distinct and very striking species, only known from Mount Wa. Neither Pratt's nor Henry's specimens are localised, but I happen to know that they were collected in the same place as my own.-E. H. W.

Rhododendron Davidii, Franch. in Bull. Soc. Bot. France xxxiii. 230. R. oreodoxa, Franch., l. c. ?

Szechuan. Wilson, 3978.

Specimens in the Kew Herbarium, received from Paris, and bearing the above names, are indistinguishable.

\section{III.-Leaves lepidote.}

Rhododendron ciliicalyx, Franch. in Bull. Soc. Bot. France xxxiii. 233 ; Hemsl in Journ. Linn. Soc. xxvi. 21.

Yunnan. A. Henry, 10,5ะ4, 11,983, 11,983a.

Rhododendron excellens, Hemsl. et E. H. Wils.; species R. Dalhousiae similis, differt calycis lobis latioribus distincte venosis, corolla extra lepidota et staminibus dimidio brevioribus.-W. B. H.

Bush, 3 m. high (Henry); branches stout, brown, lepidote. Leaves scattered, oblong, excluding petiole $15-18 \mathrm{~cm}$. long, 5.5-6 cm. 
broad, rounded or obtuse, apiculate, base somewhat narrowed, oblique, glabrous, very strongly veined, dark green, slightly wrinkled above, glaucous and lepidote beneath; midrib very much raised below ; secondary veins immersed above, very prominent beneath ; petioles very stout, nearly cylindric, $2 \cdot 5-3 \cdot 5 \mathrm{~cm}$. long. Flowers three or more, umbellate, white (Henry), $10 \mathrm{~cm}$. long, $8 \mathrm{~cm}$. broad ; pedicels stout, $2 \mathrm{~cm}$. long, erect, lepidote. Calyx petaloid, glabrous, deeply 5-lobed ; tube saucer-shaped, $1.4 \mathrm{~mm}$. deep, lepidote outside ; lobes orbicular, 6-9 $\mathrm{mm}$. long, rounded, very sparingly ciliolate. Corolla deeply campanulate, 5-lobed, lepidote outside ; tube 7.5-8 cm. long ; lobes $2-2 \cdot 5 \mathrm{~cm}$. long, broad, erect-spreading, rounded or truncate. Stamens about 12, half the length of the corolla; filaments $4-5 \mathrm{~cm}$. long, flattened and pubescent in the lower half; anthers oblong, 10-12 mm. Jong. Pistil reaching to mouth of corolla; ovary about $1.5 \mathrm{~cm}$. long, tapering to style, densely lepidote ; style stout, cylináric, lepidote in lower half; stigma large, flattened, dark-coloured. Fruit not seen.

Yunnan. South of the Red River from Mengtsze, A. Henry, 13,666 .

Undoubtedly the grandest of the Chinese Rhododendrons and comparable only with the Indian $R$. Dalhousiae, its nearest ally, from which it is easily distinguished by its more strongly veined and larger leaves, its different calyx, lepidote corolla, and stamens half the length of the corolla-tube. Henry remarks that only one specimen was brought in by a native collector.

This species is undoubtedly a native of moist warm-temperate forests, and with $R$. Falconeri forms a strong connecting link with the sub-Himalayan types of Sikkim and Assam. In view of the remarkably local distribution of most of the Chinese and Himalayan Rhododendrons, it is very surprising to find species so evidently and closely allied, separated by some fifteen degrees of longitude and by several stupendous mountain ranges.-E. H. W.

Rhododendron lutescens, Franch. in Bull. Soc. Bot. France xxxiii. 235.

Szechuan. Wilson, 3939.

Rhododendron Augustinii, Hemsl. in Journ. Linn. Soc. xxvi. 19.

Hupeh. Wilson, 302. Szechuan, Wilson, 3950.

The Szechuan specimens, from an altitude of about $3000 \mathrm{~m}$., have smaller leaves, and the under surface of the midrib is glabrous.

Rhododendron Harrovianum, Hemsl. in Gard. Chron. 1910, xlvii. 4 ; Bot. Mag. t. 8309.

Szechuax. Wilson, 1433, 3942 partly.

Cultivated specimens of this species were received from Messrs. James Veitch \& Sons, bearing the number 3942, but Wilson's dried specimens bearing this number are different.-W. B. H.

Rhododendron lepidotum, Wall. Cat.n. 758 ; Royle Illustr. Him. Pl. 260, t. 64, f. 1 ; Bot. Mag. tt. 4657, 4802 et 6450, fide C. B. Clarke in Fl. Brit. Ind. iii. 471.

YUNNAN, G. Forrest, 2505. 
Rhododendron heliolepis, Franch. in Bull. Soc. Bot. France xxxiv. 283 ; Hernsl. in Journ. Linn. Soc. xxvi. 24.

Yunvan. Monbeig, 6, 11.

Rhododendron sulfureum, Franch. in Bull. Soc. Bot. France xxxiv. 283 ; Hemsl. in Journ. Linn. Soc. xxvi. 31.

SzechuaN. Wilson, 4143.

Rhododendron Hanceanum, Hemsl. in Journ. Linn. Soc. xxvi. 24.

Szechuan. Wilson, 5141.

Rhododendron yunnanense, Franch. in Bull. Soc. Bot. France xxxiii. 232 ; Bot. Mag. t. 7614.

YUNNAN. Wilson.

Rhododendron Benthamianum, Hemsl. in Kew Bull. 1907, 319 (excl. 3940 et 3942, Wilson); Gard. Chron. 1910, xlvii. 4.

Szechuan. Wilson, 1766, 1878, 1969.

By an oversight Wilson's 3940 and 3942 (= R. concinnum, Hemsl.) were cited under the first description, and in consequence of a lapse of memory the species was described again in the Gardeners' Chronicle.-W. B. H.

Rhododendron polylepis, Franch. in Bull. Soc. Bot. France xxxiii. 232.

Szechua . Wilson, 3941, 3949.

Rhododendron concinnum, Hemsl. in Journ. Linn. Soc. xxvi. 21. R. yanthinum, Bur. et Franch. in Journ. de Bot. v. 94.

Szechuan. A. Henry, 8874 ; Pratt, 326, 848 ; Wilson 3940, 3940A, 3942 mainly.

This species was founded on an imperfect specimen collected by the Rev. Ernest Faber on the summit of Mount Omi ; but there is now ample material at Kew under the above numbers. Pratt's 848 and Wilson's 3940A differ from the type in having leaves 4 to $8 \mathrm{~cm}$. long. Messrs. James Veitch \& Sons sent cultivated specimens of the typical form to Kew in May, 1909, under the number 1524.

Rhododendron coombense, Hemsl. in Bot. Mag. t. 8:80.

Szechuan. Wilson, 1524.

Rhododendron rigidum, Franch. in Bull. Soc. Bot. France xxxiii. 233 ; Hemsl. in Journ. Linn. Soc. xxvi. 29.

Szechuan. Wilson, 3947.

Rhododendron rubiginosum, Franch. in Bull. Soc. Bot. France xxxiv. 282 ; Hemsl. in Journ. Linn. Soc. xxvi. 30.

Yunnas. G. Forrest, 2050, 2097.

Rhododendron siderophyllum, Franch. in Journ. de Bot. xii. 262.

Yunnan. A. Henry, 9110A ; Wilson, 3950 ; G. Forrest, 507.

Rhododendron moupinense, Franch. in Bull. Soc. Bot. France xxxiii. 233.

Szechuas. Wilson, 3937.

Rhododendron dendrocharis, Franch. in Bull. Soc. Bot. France xxxiii. 233.

Szechuax. A. Henry, 8857 ; Pratt, 396 ; Wilson, 3938. 


\section{Chomiastrum.}

Rhododendron Hancockii, Hemsl. in Kew Bull. 1895, 107 ; Hook. Ic. Pl. t. 2381.

Yunnan. A. Henry, 10,523A, 10,5231.

Rhododendron stamineum, Franch. in Bull. Soc. Bot. France xxxiii. 236 ; Hemsl. in Journ. Linn. Soc. xxvi. 30. R. pittosporifolium, Hemsl. in Journ. Linn. Soc. xxvi. 29. R. aucubifolium, Hemsl. in Journ. Linn. Soc. xxvi. 19, quoad flores ; folia Daphniphylli macropodi!

HupeH. A. Henry, 5787, 6432 ; Wilson, 758, 5140.

Rhododendron oxyphyllum, Franch. in Journ. de Bot. xii. 264.

Yunnan. A. Henry, 259, 331, 11,609.

This is very closely allied to, if not the same as, $R$. Westlandii, Hemsl.

Rhododendron Wilsonae, Hemsl. et $\boldsymbol{E}$. H. Wils. ; species $\boldsymbol{R}$. Westlandii simillima, differt imprimis bracteis floriferis angustis acutis.W. B. H.

Bush, 1-2 m. high ; branches slender, straight, greyish, glabrous. Leaves pseudo-verticillate, ovate-lanceolate, excluding petioles 7-10 cm. long, 2-4 cm. broad, glabrous, acuminate, base more or less cuneate, shining green, reticulate above, pallid beneath; secondary veins prominent on both surfaces; petioles about $1 \mathrm{~cm}$. long. Buds elongate-acuminate; scales reddish-brown, scarious, ovate to oblong, largest about $2 \mathrm{~cm}$. long, acute. Flowers solitary on each scaly peduncle ; peduncles clustered, forming fascicles of 4 or more at ends of shoots, flesh-pink, 4-6 cm. across ; the peduncles enclosed by sheathing bud-scales, erect-spreading, about $2 \mathrm{~cm}$. long, glabrous. Calyx annular, truncately 5-toothed, glabrous ; teeth unequal, short, rounded or acuminate. Corolla deeply 5-lobed ; tube narrowly funnel-shaped, about $1 \mathrm{~cm}$. long; lobes nearly three times as long as the tube, erect-spreading, elliptic, rounded. Stamens about ten, as long as corolla-lobes; filaments unequal, longest $3.5 \mathrm{~cm}$. long, curved, slightly villous in the lower half; anthers nearly globular. Pistil just over-topping the stamens ; ovary slender, about $7 \mathrm{~mm}$. long, glabrous, shining, reddish-brown ; style curved upwards, glabrous ; stigma capitate, flattened. Capsule cylindric, about $3 \mathrm{~cm}$. long, $0.5 \mathrm{~cm}$. broad, deeply furrowed, brown.

Huper. In woods at 1700-2000 m. above sea-level, Wilson, 317.

One of the most beautiful and distinct of Chinese Rhododendrons. Named in compliment to my wife.-E. H. W.

Rhododendron Tutcherae, Hemsl. et E. H. Wils. ; inter species sectionis 'Choniastrum' staminibus inclusis ob ramulos floriferos et folia setulosa distinctum.-W. B. H.

Tree, $13 \mathrm{~m}$. high (Henry); branches straight, setose until two years old; bark grey. Leaves clustered at ends of shoots, subcoriaceous, lanceolate, excluding petiole $8-11 \mathrm{~cm}$. long, 1.5-3 cm. broad, acuminate, base cuneate, glabrous above, setulose beneath, midrib impressed above, very prominent beneath, secondary veins raised on both surfaces; petioles about $1 \mathrm{~cm}$. long, setose. Flowers in axillary fascicles of three or more, clustered in such a way as to form a terminal truss of 12 or more flowers, violet (Henry), $5 \mathrm{~cm}$. 
across ; pedicels erect-spreading, about $1.5 \mathrm{~cm}$. long, reddish, very sparsely setose. Calyx minute, truncately 5-toothed, glandular ; teeth often unequal, very short, acute. Corolla deeply 5-lobed; tube about $1 \mathrm{~cm}$. long, narrow, nearly cylindric ; lobes three times as long as tube, spreading, elliptic, obtuse, more rarely rounded, usually with tiny apical tufts of white hairs. Stamens about ten, exserted but shorter than corolla-lobes ; filaments tomentose in lower half. Pistil over-topping stamens ; ovary slender, $0.5 \mathrm{~cm}$. long, clothed with short, white, appressed hairs ; style reddish, glabrous ; stigma large, dark-coloured. Fruit not seen.

Yunnan. Mountains south of Mengtsze, in forests at 2000 m., A. Henry, 10,636.

Named in compliment to the wife of my friend Mr. W. J. Tutcher, of Hongkong, to whom I am indebted for assistance and kind hospitality during my several visits to the island.

The section Choniastrum, Franch., in which the flowers arise either singly or in fascicles from the axils of the uppermost leaves, instead of being strictly terminal, also includes $R$. Henryi, Hance, and $\boldsymbol{R}$. Westlandii, Hemsl. All the species have very beautiful flowers.-E. H. W.

\section{Osmothames.}

Rhododendron micranthum, Turcz. in Bull. Soc. Nat. Mosc. 1837, n. vii., 155 ; Hemsl. in Journ. Linn. Soc. xxvi. 27 ; Bot. Mag. t. 8198 .

HupeH. A. Henry, 6632 ; Wilson, 1526.

Rhododendron rufescens, Franch. in Journ. de Bot. ix., 397.

Szechuan. Wilson, 3930, 3931. Yusnan. G. Forrest, 2182.

Rhododendron fastigiatum, Franch. in Bull. Soc. Bot. France xxxiii. $234 ;$ Hemsl. in Journ. Linn. Soc. xxvi. 23.

Szechuan. Pratt, 267 ; Wilson, 3936, 3936a.

Rhododendron flavidum, Franch. in Journ. de Bot. ix. 395. R. primulinum, Hemsl. in Gard. Chron. xlvii. (1910), 4.

Szechuan. Pratt, 521 ; Wilson, 1773, 3932.

Cultivated specimens, which have recently flowered with Messrs. James Veitch \& Sons at Coombe Wood, prove that $R$. primulinum, Hemsl., is not a distinct species.

Rhododendron Wongii, Hemsl. et E. H. Wils. ; ab R. flavido foliis majoribus, floribus majoribus eburneis, et calyce parvo haud petaloideo recedit : $R$. concinno etiam simile sed foliis minoribus apice rotundatis, florum colore et corolla intus extraque glabra differt.-W. B. H.

Bush, 1-2 m. high ; branches twiggy, lepidote when young. Leaves elliptic or ovate.elliptic, excluding petiole $2-3 \mathrm{~cm}$. long, $1-1.5 \mathrm{~cm}$. broad, apiculate, very dark shining green, lepidote above, grey, lepidote beneath ; petioles 3-4 mm. long, lepidote. Buds ovoid, acute ; scales obovate or spathulate, concave, rounded, apiculate, ciliate. Flowers in fascicles of three or more, cream-coloured, about $3 \mathrm{~cm}$. across ; pedicels slender, erect-spreading, $8-10 \mathrm{~mm}$. long, lepidote. Calyx saucer-shaped, lepidote, 5-toothed ; teeth 
about $1 \mathrm{~mm}$. long, orbicular, ciliate. Corolla deeply 5-lobed; tube funnel-shaped, about $1 \mathrm{~cm}$. long, pubescent inside ; lobes elliptic, about $1.5 \mathrm{~cm}$. long, spreading, rounded. Stamens about ten, shortly exserted; filaments unequal, $1 \cdot 5-2 \mathrm{~cm}$. long, villous in lower half. Pistil longer than stamens; ovary about $3 \mathrm{~mm}$. long, furrowed, densely lepidote; style filiform, sparsely pubescent at base, slightly thickened below stigma. Fruit not seen.

Szechuin. Neighbourhood of Tatienlu, on scrub-clad mountain sides, at $3650 \mathrm{~m}$. above sea-level, Wilson, 3948 .

Named in compliment to Mr. Y. C. Wrong, of Ichang, Central China, a cultured Chinese gentleman, who rendered me signal services during the whole of my stay in China.-E. H. W.

Rhododendron polycladum. Franch. in Bull. Soc. Bot. France xxxiii. $234 ;$ Hemsl. in Journ. Linn. Soc. xxvi. 29.

Szechuan. Wilson, 393.)в. Iunnan. G. Forrest, 4149.

Rhododendron blepharocalyx, Franch. in Joum. de Bot. ix. 396.

Szechuan. Pratt, 254; Vilson, 3929.

Rhododendron fragrans, Maxim. Rhod. As. Or. 16 ; Hemsl. in Journ. Linn. Soc. xxvi. 23.

Szechuan. Pratt, 660 .

Rhododendron polifolium, Franch. in Journ. de Bot. ix. 397.

Szechuas. Pratt, 787.

Rhododendron trichostomum, Franch. in Journ. de Bot. ix. 396.

Szechuas. Wilson, 3933.

Rhododendron intricatum, Franch. in Journ. de Bot. ix. 395 ; Hemsl. in Gard. Chron. 1907, xli. 262, f. iii. : Bot. May. t. 8163.

Szechuan. Wilson, 3934.

Rhododendron nigro-punctatum, Bur. et Franch. in Journ. de Bot. v. 95 .

Szechuan. Faber, 483 ; A. Henry, 8897 ; Pratt, 802 ; Wilson, 3935,3935 A.

\section{Graveolentes.}

Rhododendron brachyanthum, Franch. in Bull. Soc. Bot. France xxxiii. 234 ; Hemsl. in Jou 'n. Limn. Soc. xxvi. 20.

Yunnan. Monbeig, 9.

Rhododendron emarginatum, Hemsl. et $\boldsymbol{E}$. H. Wils.; species distincta fruticosa valde ramosa, ramis gracilibus, foliis parris subverticillatis obovatis emarginatis simul apiculatis, floribus solitariis (an semper ?) graciliter pedicellatis.-W. B. H.

Bush, $60 \mathrm{~cm}$. high (Henry) ; branches spreading (Henry), ? prostrate, twiggy, verruculose. Leaves pseudo-verticillate, obovate, excluding petioles $3-4 \mathrm{~cm}$. long, $1 \cdot 5-2 \mathrm{~cm}$. broad, rounded, emarginate, mucronulate, base narrowed to the petiole; upper surface dark green, sparsely lepidote when young; lower surface pallid, lepidote ; midrib and secondary veins immersed above, very prominent beneath ; petioles $3-5 \mathrm{~mm}$. long, lepidote. Buds ovoid, acute ; scales ovate, acute, ciliolate, very sparsely lepidote. Flovers solitary or in pairs (always?), yellow (Henry), about $1 \mathrm{~cm}$. across ; pedicels erect, 2 cm. long, lepidote. Calyx annular, 5-toothed; 
teeth minute, unequal, obtuse. Corolla campanulate, 5-lobed, lepidote outside ; lobes short, spreading, rounded. Stamens ten, included ; filaments broad, about $5 \mathrm{~mm}$. long, villous about the middle, glabrous at base. Pistil over-topping stamens; ovary $2 \mathrm{~mm}$. long, furrowed, densely lepidote. Fruit not seen.

YunNax. Mountains south-west of Mengtsze, at $2000 \mathrm{~m}$. above sea-level, A. Henry, 9166.

Very distinct from all other Chinese species. From the material before us we think the species may be prostrate in habit.-E. H. W.

Rhododendron Mariesii, Hemsl. et E. H. Wils. in Kew Bull. 1907, 244 ; Bot. Mag. t. 8206.

Kinngsi. Maries. Huper. A. Henry, 5?74.

Rhododendron mekongense, Franch. in Journ. de Bot. xii. 263.

YUnNan. Monleig, 7 ; G. Forrest, 698.

\section{Tsusia.}

Rhododendron villosum, Hemsl, et $\boldsymbol{E}$. H. Wils.; species distinctissima, etsi $R$. Championae adspectu simillima, ab eo foliis floribusque lepidotis, pilis omnibus eglandulosis, floribus minoribus et calyce parvo diversa.-W. B. H.

Bush, 1-6 m. high, much-branched, branches twiggy, sparsely lepidote, densely setose when young, becoming glabrescent with age. Leaves clustered at ends of shoots, lanceolate or oblong-lanceolate, excluding petiole $4 \cdot 5-11 \mathrm{~cm}$. (usually 7-9 cm.) long, 2-3.5 cm. broad, short or long acuminate, apiculate, base slightly auricled or cuneate, usually setulose on both surfaces (rarely pubescent beneath), becoming glabrescent with age; sparsely lepidote above, more densely so beneath ; midrib slightly immersed above, very prominent and villous beneath; secondary veins raised on upper surface ; petioles 5-8 mm. long, villous. Buds ovoid ; scales short, orbicular, apiculate, sometimes ciliolate. Flovers three or more, subumbellate, light to dark-purple, $3.5-4.5 \mathrm{~cm}$. across ; pedicels erect-spreading, 1-1.5 cm. long, pilose. Caly $x$ saucer-shaped, 5-toothed, densely villous ; teeth short, sub-orbicular, rounded, ciliate, reddish. Corolla deeply 5-lobed, sparsely lepidote ; tube narrow, funnelshaped, $1 \cdot 5-2 \cdot 5 \mathrm{~cm}$. long, more or less villous outside ; lobes about as long as tube, spreading, elliptic, rounded or obtuse. Stamens about twelve, shortly exserted ; filaments slender, $2-3.5 \mathrm{~cm}$. long, densely pilose below middle but glabrous at base. Pistil overtopping stamens ; ovary narrow, $4-7 \mathrm{~mm}$. long, densely lepidote ; style filiform, glabrous, very rarely sparsely lepidote. Capsule cylindric, lepidote, sparsely setulose, about $2 \mathrm{~cm}$. long, $\cdot 5 \mathrm{~cm}$. across, furrowed.

SzECHUAN. In thickets and thin woods, at 2300-3650 m. above sea-level, Wilson, 3944, 3945, 3946 .

The three numbers were gathered in different localities at varying altitudes ; they differ somewhat in size of leaves and in degree of hairiness of leaves and shoots.-E. H. W.

Rhododendron indicum, Sweet, Brit. Fl. Gard. ser. 2, t. 128 ; Hemsl. in Journ. Linn. Soc. xxvi. 25.-A Aalea indica, Linn. Sp. Pl. ed. 1, 150. 
Szechuan. Wilson, 5143. Yundan. A. Henry, 9900E.

Rhododendron microphyton, Franch. in Bull. Soc. Bot. France xxxiii. 235 ; Hemsl. in Journ. Linn. Soc. xxvi. 28.

Yunnan. A. Henry, 12,983; G. Forrest, 4172.

\section{KEYSIA.}

Rhododendron spinuliferum, Franch. in Journ. de Bot. ix. 399.

Yunnan. A. Henry, 10,572, 10,619.

This species was founded on Delavay's n. 4883, which is in the Kew Herbarium under another, unpublished, name. It has recently flowered in the collection of Mr. M. L. de Vilmorin, at des Barres.

\section{RHODORASTRUM.}

Rhododendron oleifolium, Franch. in Bull. Soc. Bot. France xxxiii. 235 ; Hemsl. in Journ. Iinn. Soc. xxvi. 28.

YUnNax. G. Forrest, 4132, 4133, 4170.

Rhododendron racemosum, Franch. in Bull. Soc. Bot. France xxxiii. 235 ; Hemsl. in Journ. Linn. Soc. xxvi. 29 ; Bot. Mag. t. 7301.

Yunnan. G. Forrest, 2009, 2207, 4134.

Rhododendron spiciferum, Franch. in Journ. de Bot. ix. 400.

Yunnan. A. Henry, 9369, 9369A ; G. Forrest, jl2.

Rhododendron scabrifolium, Franch. in Bull. Soc. Bot. France xxxiii. 236 ; Hemsl. in Journ. Tinn. Soc. xxvi. 30 ; Bot. Mag. t. 7159 .

YunNan. Hancock, 154.

\section{Azaleastrum.}

Rhododendron ovatum, Planch. ex Maxim. Rlood. As. ()r. 45 ; Hemsl. in Journ. Linn. Soc. xxvi. 28. - Azalea ovata, Lindl. in Journ. Hort. Soc. Lond. i. 149 ; ii. 126, t. 2 ; Bot. Mag. t. 5064.

HuPEH. Wilson, 719 .

\section{XVII.-AN ATTEMPT TO INTRODUCE OLEARIA SEMIDENTATA INTO THE BRITISH ISLES.}

(With Plates.)

\section{A. A. Dorrien-Suith.}

Captain A. A. Dorrien-Smith, who has just returned from an expedition to Western Australia, New Kealand, and Chatham Island, has sent the following account of his experiences in Chatham Island for publication in the Ker Bulletin. Captain DorrienSmith has brought home to the Scilly Islands a large number of interesting plants, but he informs us that, owing to the heat experienced on the voyage from Monte Video to lat. $10^{\circ} \mathrm{N}$., the Chatham Island plants suffered severely and only a very small proportion managed to survive. 